\title{
Traumatic extraction of upper central incisors
}

\author{
Svjetlana Janković1, Aleksandra Žuža², Bojana Davidović', Ivana Simić3, Lado Davidoviće,1 \\ ${ }^{1}$ University of East Sarajevo, Faculty of Medicine, Department of Children and Preventive Dentistry and Orthodontics, \\ Foča, Republika Srpska, Bosnia and Herzegovina; \\ University of East Sarajevo, Faculty of Medicine, Department of Dental Pathology, Foča, Republika Srpska, Bosnia and \\ Herzegovina; \\ ${ }^{3}$ University of East Sarajevo, Faculty of Medicine, Department of Oral Rehabilitation, Foča, Republika Srpska, Bosnia and \\ Herzegovina
}

\begin{abstract}
SUMMARY
Introduction Tooth and other oral tissue damage can occur at any time of life. Traumatic extraction is a complex traumatic injury characterized by complete dislodgement of the tooth from its alveolus. The diagnosis of traumatically injured teeth includes $\mathrm{X}$-rays and a detailed clinical examination.

Case report A twelve-year-old boy reported at the dental clinic of the Faculty of Medicine due to the injury in the anterior maxillary region. It was a sport injury. The time elapsed since the accident was 2 hours and 20 minutes. According to the clinical examination and X-rays the diagnosis was: The teeth 11 and 21 - Complete traumatic dental avulsion and fracture; 22- Hypodontia and chin contusion and laceration. The teeth were brought in physiological solution. After applying local anesthetic, soft tissue was cleaned, the teeth positioned back in their alveoli and an immobilizing splint of fiberglass fibers placed. The patient was administered antibiotics and recommended tetanus prophylaxis. Seven days after the injury, teeth were treated endodontically. After one month, the immobilizing splint was removed. The tooth 21 was definitely obturated and composite buildups were done on both teeth. Calcium hydroxide dressing was left in the canal of the tooth 11. One month and 3 weeks after the injury, a fistula appeared above the tooth 11, and the treatment was finally completed after seven months.

Conclusion Traumatic tooth injuries, of any kind, require urgent treatment as time loss usually reduces chances for successful treatment. One year after the injury, the patient had no symptoms and the result was functional and aesthetically acceptable.
\end{abstract}

Keywords: avulsion; trauma; teeth extraction; immobilization splint

\section{INTRODUCTION}

Traumatic injuries of teeth and other oral tissues can occur at any time of life. They happen usually between 1-3 years in primary and 8-11 years in permanent dentition $[1,2]$. The most commonly affected teeth are upper central and lateral maxillary incisors that are more exposed to injuries due to anterior position [3]. Injuries of anterior teeth can lead to phonetic, functional, aesthetical problems as well as disorders in occlusion [1]. Preliminary studies suggest that boys are more prone to trauma [4-8].

Traumatic tooth extraction (Avulsio completa, Extrusio completa, Luxatio completa dentis, Exarticulatio completa) is a complete loss of a tooth from the alveolus and it is one of the most serious tooth injuries. Although clinically visible alveolus is easily detected, the diagnosis of traumatic tooth injuries is only established after the $\mathrm{X}$-ray examination. Differential diagnostic considerations are tooth inntrusion (Intrusio dentis) and root fracture with the loss of crown (Fractura radicis dentis). The main cause of traumatic extraction in primary dentition is fall, while in permanent dentition it is direct (frontal) stroke of the tooth. The frequency of these injuries in primary dentition is $7 \%$, while in permanent dentition it is lower and about $0.9 \%$ of all tooth injuries [9].

Traumatic tooth injuries of any kind require immediate treatment as any loss of time reduces the chances of successful treatment. In the case of tooth avulsion, the success of tooth replantation, posttraumatic period, as well as the possibility and the rate of complications, depends on numerous factors [10]. The most important are: the time between the injury and the time of tooth replantation, the way tooth is kept during this time period, the stage of development of the root, the condition of alveolar bone, the preliminary condition of the crown of the tooth, pulp and periodontal ligament, the existence of possible orthodontic irregularities as well as the replantation procedure itself [11]. Although long-term prognosis for retaining tooth in the jaw is not certain, due to the importance of preserving the height of alveolar ridge, function, phonetics and esthetics, it is always important to try replantation if there are adequate conditions for it.

The aim of this paper was to show the procedure, the treatment and complications after the tooth avulsion. 


\section{CASE REPORT}

A 12-year-old boy visited nearest dental clinic in Visegrad due to a tooth injury in the upper jaw after falling during sport activity. Patient gave a history of the fall and he did not show any signs or symptoms of neurological damage. Due to the lack of material for the immobilization splint, the boy was sent to a dental clinic at the Faculty of Medicine in Foca. After obtaining accident history and performed clinical examination (Figure 1) and X-ray (Figure 2), the following diagnosis was made: The teeth 11 and 21 - Complete traumatic dental avulsion; 22- Hypodontia; 11 - Traumatic tooth fracture class I; 21 - Traumatic tooth fracture class II as well as chin contusion and laceration.

The teeth were transported in a glass bottle with physiological solution (Figure 3). The available treatment options were explained to the parents. After 2 hours and 20 minutes, the replantation procedure was performed as per recommendation of The International Association of Dental Traumatology - IADT [12]. Local anesthesia was administered. In order to remove impurities and blood clots, injured region was cleaned with sterile gauze soaked with saline. Removal of soft deposits from adjacent teeth

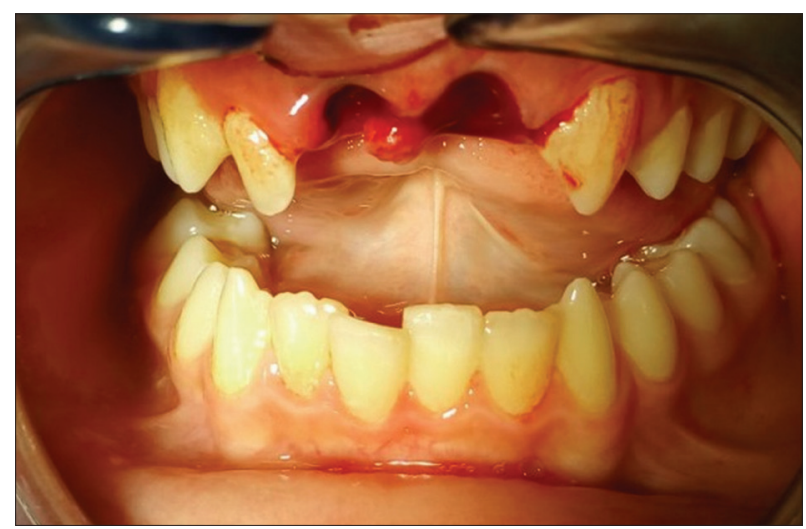

Figure 1. Traumatic dental avulsion of teeth 11,21

Slika 1. Avulsio completa dentes traumatic zuba 11, 21

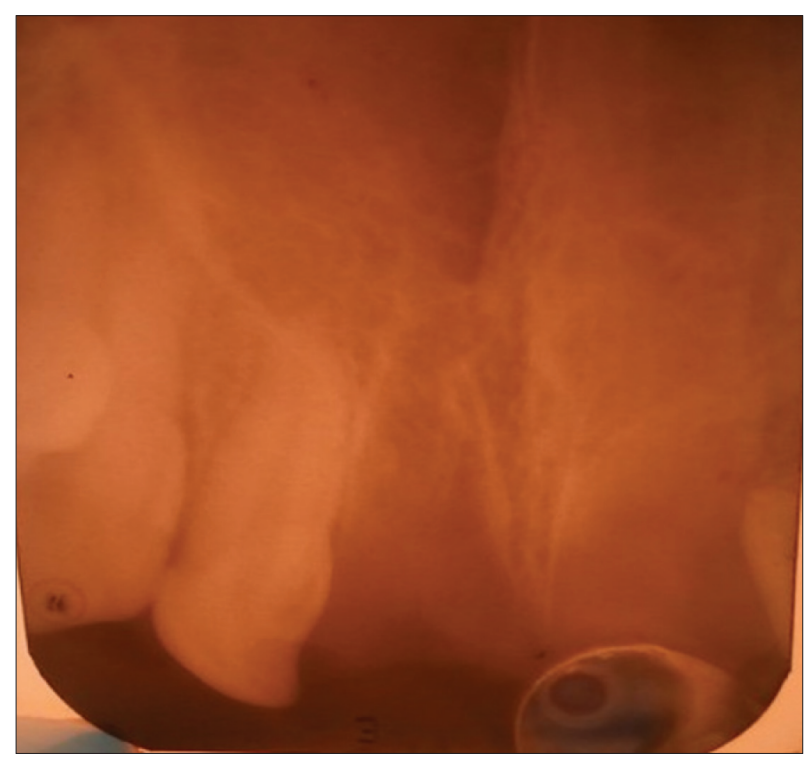

Figure 2. $X$ ray of the teeth 11,21

Slika 2. RTG snimak zuba 11, 21 on which the splint was to be placed was performed. 37\% orthophosphoric acid was applied for 30 seconds (Figure 4). After rinsing and drying (Figure 5), an adhesive was placed. During this time, the avulsed teeth were removed from the transport medium, carefully rinsed with saline and on the vestibular surface of the crown the same procedure of etching with the acid (Figure 6) and adhesive was performed. The alveoli were rinsed with saline and avulsed teeth were slowly replanted using digital pressure only. An immobilizing splint was installed (Figure 7). The time elapsed from the moment of injuries to the completion of replantation was 2 hours and 45 minutes. Tetanus prophylaxis was recommended, tetracycline antibiotics prescribed for 5 days and analgesics as needed. Patient was advised to take soft diet and maintain good oral hygiene. The postop checkup was scheduled 7 days after.

At the first checkup, the replanted teeth were mostly firm and stable on mild palpation. After clinical and radiographical evaluation root canal was performed on both teeth 11 and 21 according to the standard procedure. After copious irrigation with physiological solution and drying the canal with paper points, the teeth were filled with calcium hydroxide (Calcipulpe ${ }^{\circledast}$ Septodont, Cedex, France) and patient was scheduled for the next checkup in 7 days. At the second checkup, 15 days after the injury, the re-

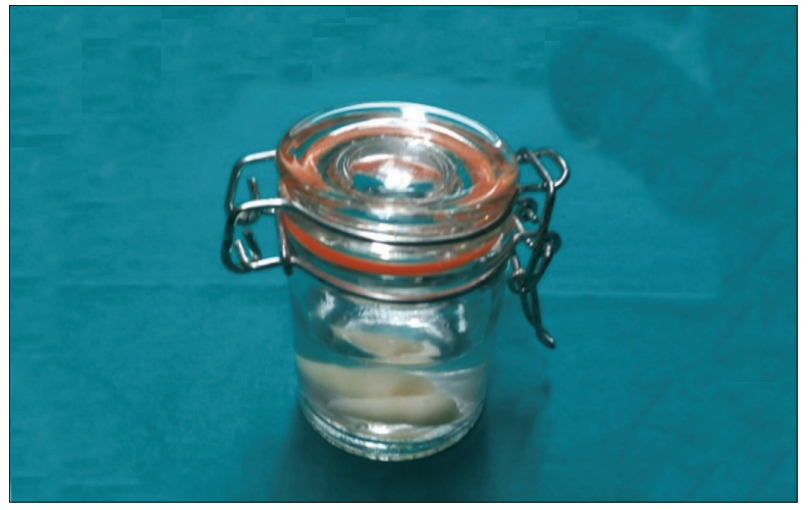

Figure 3. Glass jar with a physiological solution in which the teeth 11 and 21 were transported

Slika 3. Staklena teglica sa fiziološkim rastvorom u kojoj su doneseni zubi 11, 21

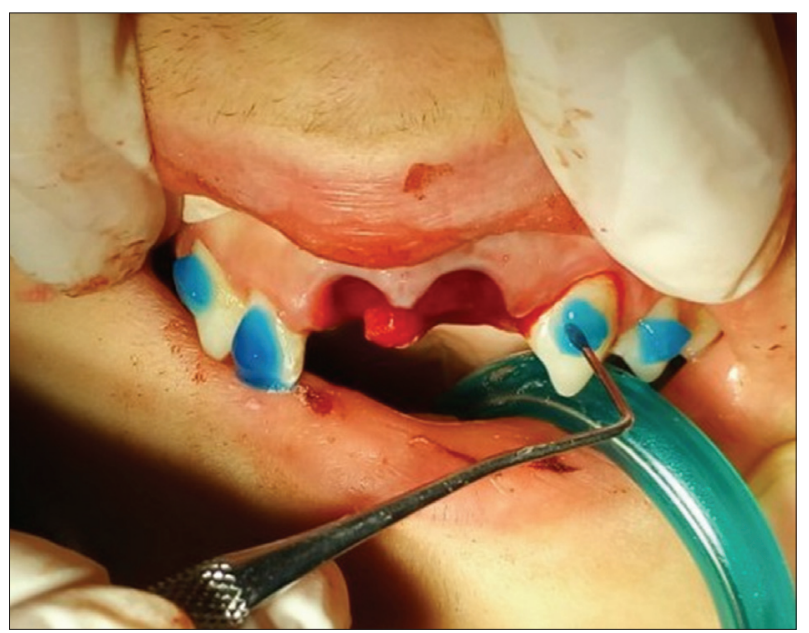

Figure 4. Orthophosphoric acid application on adjacent teeth Slika 4. Postavljanje ortofosforne kiseline na susedne zube 


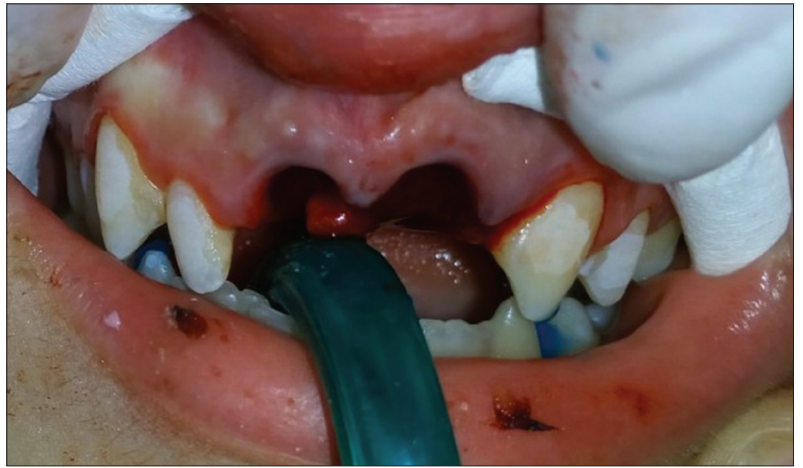

Figure 5. The teeth after rinsing orthophosphoric acid Slika 5. Izgled zuba posle nagrizanja kiselinom

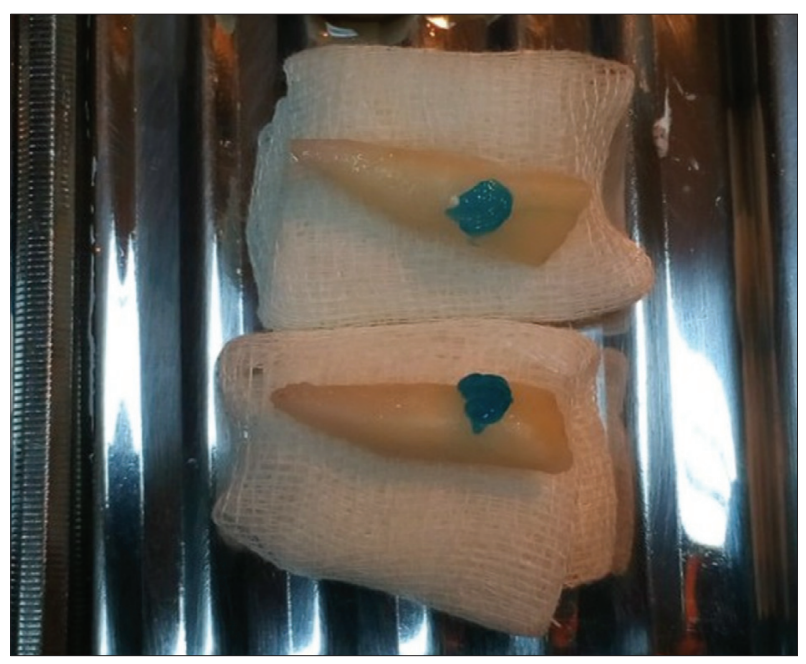

Figure 6. Orthophosphoric acid applied on avulsed teeth Slika 6. Tretiranje izbijenih zuba ortofosfornom kiselinom

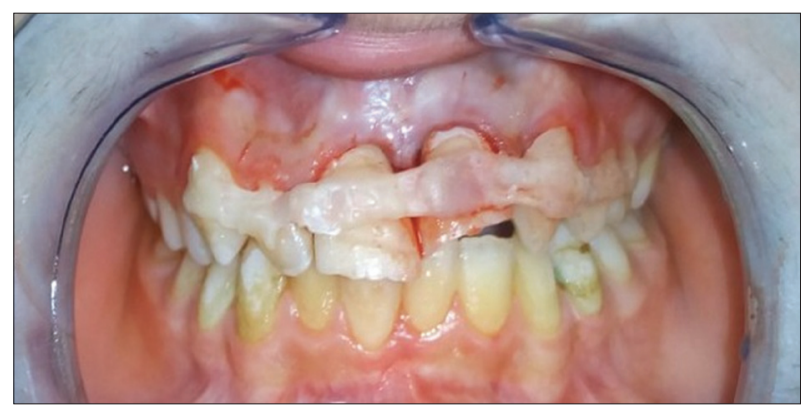

Figure 7. Immobilization splint in situ Slika 7. Izgled imobilizacionog splinta

planted teeth were not completely firm to palpation, while on the mild vertical and horizontal percussion they were sensitive, especially the tooth 11 . Taking into account the size of the injured area, hypodontia of the tooth 22 , the time that elapsed from the moment of injury to teeth replantation, the immobilizing splint was kept in place for another two weeks. One month after the injury, calcium hydroxide dressing was removed, canals irrigated with $2 \%$ sodium hypochlorite solution and physiological solution. The $\mathrm{X}$ ray examination was done. Due to the satisfactory clinical and radiological findings the tooth 21 was finally obturated while calcium hydroxide was placed back in the canal of the tooth 11. In the same visit, the immobilization splint was removed. Then after, the teeth that were in the splint were treated with Fluorogal $^{\circledR}$ Forte Gel, Galenika A.D.

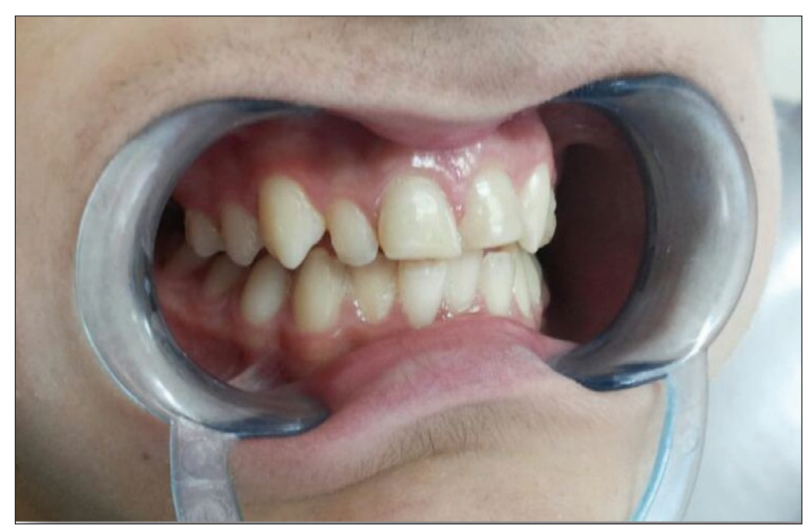

Figure 8. Composite buildups on the teeth 11, 21

Slika 8. Urađene kompozitne nadogranje na zubima 11, 21

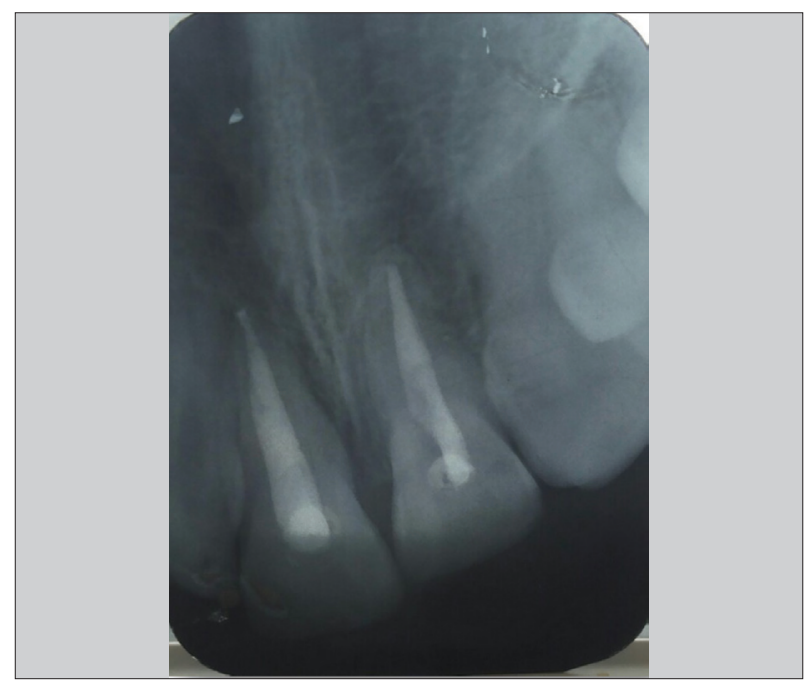

Figure 9. Definitive root canal obturation on teeth 11, 21 after one year

Slika 9. Definitivno punjenje korenskih kanala 11, 21 posle godinu dana

Belgrade. The patient was scheduled for another visit in three days. After 1 month and 3 days, composite buildups were done on both teeth, 11 and 21. The tooth 21 was definitely obturated (Gutaperka points and pastes for definitive obturation) while on the tooth 11 root canal treatment continued until all symptoms of chronic infection were gone. After 1 month and 3 weeks, a fistula appeared above the root of the tooth 11. Calcium hydroxide was replenished every month, and seven months after the injury, the tooth 11 was definitely obturated. One year after the injury, the patient did not have any subjective sympthoms, and the result achieved was functionally and aesthetically acceptable (Figure 8). However, $\mathrm{X}$ ray showed the initial signs of internal resorption of the tooth 21 (Figure 9). The patient has been monitoring on regular checkups scheduled every six months patient for up to 5 years.

\section{DISCUSSION}

It has been recommended in some studies that every avulsed tooth should be replanted regardless of the time between the accident and replantation [9]. Considering 
the age of the patient, the size of injured area, the way the teeth were kept in saline, and hypodontia of the tooth 22, replantation was also chosen in our case. The parents were presented with options and minimal chances for successful treatment of teeth replantation. Also they understood posttraumatic period and possible complications.

Extraalveolar time can be short (less than $20 \mathrm{~min}$ ), medium (20-60 min) and long (more than $60 \mathrm{~min}$ ). Although for our patient extraalveolar time was long ( 2 hours and 20 minutes after the injury), avulsed central incisors were replanted and the immobilization splint was placed. It is believed that periodontal ligament maintains its vitality within the first 20 minutes of the injury $[12,13,14]$. The teeth replanted within that time frame have the best prognosis and the greatest possibility for healing of periodontal ligaments [12]. However, the literature presents cases of tooth restoration even after 36 hours of injury [15]. Ideally, avulsed tooth is to be returned to the alveolus immediately after the injury occurs. If this is not done, it is necessary to put the tooth in the transport medium and, as soon as possible, refer patient to the dentist. The type of media in which the tooth is stored determines the long-term prognosis of the replanted tooth. Ideal medium should preserve most of functional capabilities of periodontal ligament cells [14]. The tooth must not be dried or transported in dry, which occurs when wrapping in wipes and gauze or similar things. This leads to dehydration of still preserved cells on the surface of root that start to die in dry medium. There are various media for storing avulsed teeth that are widely available (water, saliva, saline, milk, ...) as well as specialized media. Water can protect the tooth from dehydration but if it is used for more than 20 minutes it leads to rapid deterioration of periodontal ligament cells [16].

Saliva is easily accessible and favorable storage medium if used for less than one hour. Research has shown that saline as an environment for storing avulsed teeth can also be harmful to periodontal ligament cells if used for more than two hours because there are not enough essential nutrients such as magnesium, calcium and glucose, which are important for the metabolic needs of periodontal cells [17]. Modern research suggests that milk is an excellent storage medium for up to 6 hours because it does not have bacteria and has $\mathrm{pH}$ and osmolality compatible with those of the periodontal ligament cell and has nutrients such as amino acids, carbohydrates and vitamins $[9,18,19]$. There are several types of special media for transportation of avulsed teeth: Hank's Balanced Saline Solution (HBSS), DentoSafe and ViaSpan media for tissue and organ transplantation $[3,19]$. Today, DentoSafe (Dentosafe GmbH, Iserlohn, Germany) is considered to be the most appropriate media for preserving and transporting avulsed tooth [16], and therefore DentoSafe vials should be available in all places at risk of dental trauma such as schools, daycares, children's playgrounds and sport fields.

Endodontic treatment of injured teeth, in our patient, started after seven days. Some authors point out that, in order to prevent necrosis of the pulp of the avulsed tooth, it is necessary to start the root canal treatment for 7-10 days from avulsion [14], which is in accordance with our procedure. Any further delay greatly increases the risk of post-implantation necrosis and loss of teeth [16]. Postdental trauma complications can occur in pulp, periodontal ligament, and surrounding structures. The most common are pulp necrosis [20] and root resorption [10, $21]$. One month and 3 weeks after the injury a fistula appeared above one replanted tooth (11) in our case. There was also palpation and percussion sensitivity on the same tooth. Some authors suggest that optimal length of having the immobilization splint, for regeneration of periodontal ligament is two weeks $[12,16]$. Due to the size of traumatic field and hypodontia of the tooth 22 our patient wore a splint longer than recommended time. In our case the patient had two avulsed teeth even though the most common is just one affected tooth [3].

Trauma has serious aesthetical, functional, psychologi$\mathrm{cal}$ and economic consequences for patients and their parents $[16,22]$. Our patient and his parents were unaware that teeth can be replanted back to their place until dentist suggested such an intervention. Other studies conducted on this topic have also shown that parents' knowledge of tooth injuries and possible treatment is inadequate [22, 23]. Everyone involved in childcare should be properly educated in prevention and treatment of all kinds of dental trauma. Replantation of avulsed tooth in children is not important only from functional point, but it also has great psychological, emotional and social significance both for the child and parents.

\section{CONCLUSION}

Early tooth loss has a negative impact on child's psychosocial development. It is therefore important to educate parents and all childcare personnel (educators, teaching staff, trainers) about injury prevention, urgent treatment, possibilities of replantation of avulsed teeth, as well as the procedure and possible way of transporting avulsed teeth. Transporting mediums for avulsed teeth should be available in all daycares, schools and sports clubs. In addition children involved in sport activities should be wearing sport guards.

\section{REFERENCES}

1. Sari ME, Ozmen B, Koyuturk AE, Tokay U, Kasap P, Guler D. A retrospective evaluation of traumatic dental injury in children who applied to the dental hospital, Turkey. Niger J Clin Pract. 2014; 17(5):644-8. [DOI: 10.4103/1119-3077.141438] [PMID: 25244279]

2. Bücher K, Neumann C, Hickel R, Kühnisch J. Traumatic dental injuries at a German university clinic 2004-2008. Dent Traumatol. 2013; 29(2):127-33. [DOI: 10.1111/j.1600-9657.2012.01149.x] [PMID: 22613081]

3. Karayilmaz H, Kirzioglu Z, Erken Gungor O. Aetiology, treatment patterns and long-term outcomes of tooth avulsion in children and adolescents. Pak J Med Sci. 2013; 29(2):464-8. [PMID: 24353557]

4. Hasan AA, Qudeimat MA, Andersson L. Prevalence of traumatic dental injuries in preschool children in Kuwait-a screening study. Dent Traumatol. 2010; 26(4):346-50.

[DOI: 10.1111/j.1600-9657.2010.00891.x] [PMID: 20662888] 
5. Zaleckiene V, Peciuliene V, Brukiene V, Drukteinis S. Traumatic dental injuries: etiology, prevalence and possible outcomes. Stomatologija. 2014; 16(1):7-14. [PMID: 24824054]

6. Schuch HS, Goettems ML, Correa MB, Torriani DD, Demarco FF. Prevalence and treatment demand after traumatic dental injury in South Brazilian schoolchildren. Dent Traumatol. 2013; 29(4):297302. [DOI: 10.1111/edt.12003] [PMID: 23067235]

7. Abukabbos H, Al Sineedi F, Guelmann M. Management of complications after traumatic injuries to immature permanente maxillary incisors: a five years follow up case report. Oral Health Dent Manag. 2014; 13(2):429-34 [PMID: 24984660]

8. Lam R. Epidemiology and outcomes of traumatic dental injuries: a review of the literature. Aust Dent J. 2016; 61:S4-20. [DOI: 10.1111/adj.12395] [PMID: 26923445]

9. Šurdilović $D$, Apostolović $M$, Igić $M$, Kostadinović Lj, Tričković Janjic O. Therapy of the patient having traumatic extraction of permanent upper central incisors. Acta Stomatologica Naissi 2008; 24:833-40

10. Niikuni N, Seki N, Sato K, Nasu D, Shirakawa T. Traumatic injury to permanent tooth resulting in complete root resorption: a case report. J Oral Sci. 2007; 49(4):341-4. [DOI: 18195520] [PMID: 18195520]

11. Beloica D, Vulović M, Duggal M, Dimitrijević B. Povrede zuba. Stomatološki fakultet, Univerzitet u Beogradu. 2007.

12. Flores MT, Andersson L, Andreasen JO, Bakland LK, Malmgren $B$, Barnett $F$, et al. Guidelines for the management of traumatic dental injuries. II. Avulsion of permanent teeth. Dent Traumatol. 2007; 23(3):130-6. [DOI: 10.1111/j.1600-9657.2007.00605.x] [PMID: 17511833]

13. Panzarini SR, Trevisan CL, Brandini DA, Poi WR, Sonoda CK, Luvizuto ER, et al. Intracanal dressing and root canal filling materials in tooth replantation: a literature review. Dent Traumatol. 2012; 28(1):42-8. [DOI: 10.1111/j.1600-9657.2011.01023.x] [PMID: 22230725]

14. Andreasen JO, Borum MK, Jacobsen HL, Andreasen FM. Replantation of 400 avulsed permanent incisors. 4. Factors related to periodontal ligament healing. Endod Dent Traumatol. 1995; 11(2):76-89. [PMID: 7641622]

15. Adil NF, Ahmed SS, Jindal MK, Arshad SH. Delayed replantation of avulsed teeth. J Indian Soc Pedod Prev Dent. 2007; 25:17-9. [PMID: 17921635]

16. Škrinjarić I, Škrinjarić T, Goršeta K, Čuković-Bagić I, Verzak Ž. Hitni i preventivni postupci kod trauma zuba u djece. Paediatr Croat. 2010; 54 (Supl 1):154-62

17. Pohl Y, Tekin U, Boll M, Filippi A, Kirschner H. Investigations on a cell culture medium for storage and transportation of avulsed teeth. Aust Endod J. 1999; 25(2):70-5. [PMID: 11411083]

18. Blomlof L. Milk and saliva as possible storage media for traumatically exarticulated teeth prior to replantation. Swed Dent J. 1981; (Supl 8):1-26. [PMID: 6942523]

19. Trope M, Friedman S. Periodontal healing of replanted dog teeth stored in ViaSpan, milk, Hanks balanced salt solution. Endodon Dent Traumatol. 1992; 8(5):183-8. [PMID: 1302677]

20. Wang SH, Chung MP, Su WS, Cheng JC, Shieh YS. Continued root formation after replantation and root canal treatment in an avulsed immature permanent tooth: a case report. Dent Traumatol. 2010; 26(2):182-5. [DOI: 10.1111/j.1600-9657.2010.00864.x] [PMID: 20486947]

21. Donaldson M, Kinisons MJ. Factors affecting the time of onset of resorption in avulsed and replanted incisor teeth in children. Dent Traumatol. 2001; 17(5):205-9. [PMID: 11678538]

22. Ozer S, Yilmaz El, Bayrak S, Tunc ES. Parental knowledge and attitudes regarding the emergency treatment of avulsed permanent teeth. Eur J Dent. 2012; 6(4):370-5. [PMID: 23077415]

23. Fujita $Y$, Shiono $Y$, Maki K. Knowledge of emergency management of avulsed tooth among Japanese dental students. BMC Oral Health. 2014; 14:34. [DOl: 10.1186/1472-6831-14-34] [PMID: 24712491] 


\title{
Traumatska ekstrakcija gornjih centralnih sekutića
}

\author{
Svjetlana Janković ${ }^{1}$ Aleksandra Žuža², Bojana Davidović', Ivana Simić3 , Lado Davidović \\ 'Univerzitet u Istočnom Sarajevu, Medicinski flakultet Foča, Katedra za dječiju i preventivnu stomatologiju sa ortodoncijom, Foča, \\ Republika Srpska, Bosna i Hercegovina; \\ 2Univerzitet u Istočnom Sarajevu, Medicinski fakultet Foča, Katedra za dentalnu patologiju, Foča, Republika Srpska, Bosna i \\ Hercegovina; \\ 3Univerzitet u Istočnom Sarajevu, Medicinski flakultet Foča, Katedra za oralnu rehabilitaciju, Foča, Republika Srpska, Bosna i \\ Hercegovina
}

\begin{abstract}
KRATAK SADRŽAJ
Uvod Povrede zuba i drugih oralnih tkiva mogu nastati u bilo kom periodu života. Traumatska ekstrakcija zuba je potpuno izbijanje zuba iz alveole. Dijagnoza traumatski izbijenih zuba postavlja se tek posle analize rendgen snimka, kao i detaljnog kliničkog pregleda. Prikaz slučaja Pacijent uzrasta 12 godina javio se na Stomatološku kliniku Medicinskog fakulteta u Foči zbog povrede u frontalnoj regiji maksile. Uzrok povrede je pad u toku sportskih aktivnosti. Vreme proteklo od povrede je dva sata i 20 minuta. Kliničkim pregledom i rendgen snimkom dijagnostikovano je: 11 i 21 - Avulsio completa dentes traumatica et Fractura dentes traumatica; 22 - Hypodontia dentis i Vulnus laceratio contusus mentae. Zubi su doneseni u fiziološkom rastvoru. Posle obrade rane i date anestezije zubi su vraćeni u alveolu i postavljen je imobilizacioni splint od fiberglas vlakana. Pacijentu su prepisani antibiotici i preporučena antitetanus zaštita. Sedam dana od povrede zubi su endodontski tretirani. Mesec dana od povrede uklonjen je splint, zub 21 je definitivno napunjen i na oba zuba urađene su kompozitne nadogradnje. U zubu 11 ostavljeno je punjenje kalcijum-hidroksidom. Mesec dana i tri sedmice od povrede pojavila se fistula iznad zuba 11. Endodontsko lečenje ovog zuba je završeno posle sedam meseci. Zaključak Traumatske povrede zuba, bilo koje vrste, zahtevaju hitan tretman. Svaki gubitak vremena umanjuje verovatnoću da će lečenje biti uspešno. Godinu dana od povrede pacijent nema nikakvih subjektivnih smetnji, a postignut rezultat je funkcionalno $i$ estetski prihvatljiv.
\end{abstract}

Ključne reči: avulzija; trauma; ekstrakcija zuba; imobilizacioni splint

\section{UVOD}

Traumatske povrede zuba i drugih oralnih tkiva mogu nastati u bilo kom periodu života. Javljaju se uglavnom između prve i treće godine u mlečnoj i osme i jedanaeste godine u stalnoj denticiji $[1,2]$. Najčešće zahvaćeni zubi su gornji centralni i lateralni maksilarni incizivi, koji su zbog anteriorne pozicije i najosetljiviji na povrede [3]. Povrede prednjih zuba mogu dovesti do fonetičkih, funkcionalnih i estetskih problema, kao i do poremećaja u okluziji [1]. Prethodne studije ukazuju da su traumama skloniji dečaci [4-8].

Traumatska ekstrakcija zuba (Avulsio completa, Extrusio completa, Luxatio completa dentis, Exarticulatio completa) potpuno je izbijanje zuba iz alveole i istovremeno predstavlja jednu od najtežih povreda zuba. Iako se klinički lako uočava prazna alveola, dijagnoza traumatski izbijenih zuba postavlja se tek posle analize rendgen snimka. Diferencijalno dijagnostički u obzir dolazi utisnuće zuba (Intrusio dentis), kao i prelom korena sa gubitkom kruničnog dela zuba (Fractura radicis dentis). Osnovni uzrok traumatske ekstrakcije kod mlečnih zuba je pad, dok je kod stalnih zuba direktni (frontalni) udarac u zub. Učestalost ove povrede u mlečnoj denticiji je 7\%, dok je u stalnoj denticiji nešto ređa i kreće se oko $0,9 \%$ od svih povreda zuba [9].

Traumatske povrede zuba, bilo koje vrste, zahtevaju hitan tretman jer svaki gubitak vremena umanjuje verovatnoću da će lečenje biti uspešno. Kada je avulzija zuba u pitanju, uspešnost replantacije zuba, posttraumatski period, kao i mogućnost i brzina nastanka komplikacija, zavise od brojnih faktora [10]. Najvažniji su: vreme koje je proteklo od traumatske ekstrakcije do replantacije, način čuvanja zuba od trenutka izbijanja do replantacije, stepen razvoja korena izbijenog zuba, stanje alveolrane kosti, prethodno stanje krunice zuba, pulpe i parodoncijuma, postojanje eventualne ortodontske nepravilnosti, kao i postupak pri samoj replantaciji [11]. Iako dugoročna prognoza da će zub ostati u vilici nije sigurna, zbog važnosti očuvanja visine alveolarnog grebena, funkcije, fonetike ali i estetike, uvek treba pokušati uraditi replantaciju ako za to postoje adekvatni uslovi.

Cilj ovoga rada bio je da prikaže postupak, terapiju i komplikacije posle avulzije zuba.

\section{PRIKAZ SLUČAJA}

Dvanaestogodišnji dečak javio se u najbližu stomatološku ambulantu u Višegradu zbog povrede zuba u gornjoj vilici posle pada tokom treniranja fudbala. Anamnestički podaci ukazuju da pacijent nije pokazivao znake i simptome neurološkog oštećenja. Zbog nedostatka materijala za postavljanje imobilizacionog splinta, dečak je upućen na Stomatološku kliniku Medicinskog fakulteta u Foči. Posle uzete anamneze, urađenog kliničkog pregleda (Slika 1) i RTG snimka (Slika 2) postavljena je sledeća dijagnoza: 11 i 21 - Avulsio completa dentes traumatica; 22 Hypodontia dentis. Takođe je dijagnostikovano: 11 - Fractura dentis traumatica I klase; 21 - Fractura dentis traumatica II klase i Vulnus laceratio contusus mentae.

Zubi su transportovani u staklenoj bočici sa fiziološkim rastvorom (Slika 3). Roditeljima su objašnjene dostupne terapijske mogućnosti. Posle dva sata i 20 minuta pristupilo se postupku replantacije, po preporukama Internacionalne asocijacije dentalne traumatologije - IADT [12]. Aplikovana je lokalna anestezija. Da bi se uklonile nečistoće i krvni ugrušci, povređena regija je tretirana sterilnom gazom natopljenom u fiziološki rastvor. Izvršeno je uklanjanje mekih naslaga sa zuba na koje će biti postavljen imobilizacioni splint. Potom je urađeno nagrizanje 37\% ortofosfornom kiselinom u trajanju od 30 sekundi (Slika 4). Posle ispiranja i posušivanja (Slika 5), postavljen je adheziv. Tokom 
ovog perioda izbijeni zubi su uklonjeni iz transportnog medijuma, pažljivo isprani fiziološkim rastvorom i na vestibularnim površinama zuba ponovljena je ista procedura sa kiselinom (Slika 6) i adhezivom. Alveola je isprana sa fiziološkim rastvorom i izbijeni zubi su lagano replantirani digitalnom kompresijom. Postavljen je imobilizacioni splint (Slika 7). Vreme proteklo od momenta povređivanja do završetka replantacije je dva sata i 45 minuta. Preporučena je antitetanusna profilaksa, propisani su tetraciklinski antibiotici u trajanju od pet dana i analgetici po potrebi. Pacijentu je savetovano da jede mekanu hranu i održava oralnu higijenu. Kontrola je zakazana za sedam dana.

Na prvoj kontroli replantirani zubi su bili u velikoj meri čvrsti i stabilni na palpaciju. Posle kliničke i radiološke procene sproveden je endodontski tretman na zubima 11 i 21 po standardnoj proceduri. Zubi su napunjeni kalcijum-hidroksidom (Calcipulpe ${ }^{\circledast}$ Septodont, Cedex, France) posle obilne irigacije fiziološkim rastvorom i posušivanja papirnim poenima Naredna kontrola je zakazana za sedam dana. Na drugoj kontroli, 15 dana od povrede, replantirani zubi nisu bili potpuno čvrsti na palpaciju, dok su na blagu vertikalnu i horizontalnu perkusiju bili osetljivi, posebno zub 11. Imajući u vidu veličinu povređenog područja, urođeni nedostatak zuba 22, vreme koje je proteklo od momenta povređivanja do replantacije, odlučeno je da splint ostane još neko vreme. Na oba zuba ponovljeno je punjenje kalcijum-hidroksidom i pacijentu je zakazan kontrolni pregled za dve sedmice. Posle mesec dana uklonjeno je prethodno punjenje, izvršena obilna irigacija $2 \%$ natrijum-hipohloritom, a zatim fiziološkim rastvorom, i kanal je ponovo napunjen kalcijum-hidroksidom. Urađen je RTG snimak.

Zbog zadovoljavajućeg kliničkog nalaza zub 21 je opturisan. $\mathrm{U}$ istoj poseti uklonjen je imobilizacioni splint. Posle uklanjanja splinta, zubi koji su bili u splintu tretirani su Fluorogal ${ }^{\circledR}$ Forte gelom, Galenika A.D. Beograd. Pacijentu je zakazana naredna kontrola za tri dana. Posle jednog meseca i tri dana, na oba zuba, 11 i 21, urađene su kompozitne nadogradnje. Zub 21 bio je definitivno napunjen (gutaperka poeni i pasta za definitivnu opturaciju kanala), dok se na zubu 11 lečenje korenskog kanala nastavilo i dalje do potpunog smirivanja svih simptoma hronične infekcije. Polse jednog meseca i tri sedmice, iznad zuba 11 pojavila se fistula. Punjenje je menjano svakih mesec dana, a nakon sedam meseci od povrede zub 11 je definitivno zbrinut $i$ napunjen pastom za definitivnu opturaciju kanala. Godinu dana od povrede pacijent nije imao nikakvih subjektivnih smetnji, a postignuti rezultat je funkcionalno i estetski prihvatljiv (Slika 8). Međutim, na RTG snimku oko zuba 21 uočavaju se početni znaci interne resorpcije (Slika 9). Pacijent se i dalje prati na redovnim kontrolama, koje se zakazuju na šest meseci, i biće opserviran još najmanje pet godina.

\section{DISKUSIJA}

Kada je traumatska ekstrakcija zuba u pitanju, pojedine studije pokazuju da je replantaciju zuba potrebno sprovesti bez obzira na to kada se pacijent javi [9]. S obzirom na uzrast pacijenta, veličinu povređenog polja, način na koji su zubi doneseni, kao i urođeni nedostatak zuba 22, nije preostalo ništa drugo nego da se pokuša sa replantacijom. Roditeljima je ukazano da postoje šanse, mada minimalne, da se zubi sačuvaju. Takođe su upoznati sa posttraumatskim tokom i mogućim komplikacijama.
Razlikuje se kratko (manje od 20 min.), srednje (20-60 min.) i dugo (više od $60 \mathrm{~min}$.) ekstraalveolarno vreme. Iako je ekstraalveolarno vreme kod našeg pacijenta dugo (prošlo je dva sata i 20 minuta od povrede), traumatski izbijeni centralni sekutići su vraćeni u alveolu i postavljen je imobilizacioni splint. Smatra se da periodontalni ligament održava svoju vitalnost u prvih 20-ak minuta od povrede $[12,13,14]$.Zubi koji su replantirani u okviru tog vremena imaju najbolju prognozu i najveću mogućnost za ozdravljenje periodontalnog ligamenta [12]. Međutim, u literturi su opisani slučajevi vraćana zuba i nakon 36 sati od povrede [15].

Najbolja prognoza bi bila da su pacijentu zubi vraćeni u alveolu neposredno posle povrede. Kada to nije urađeno, zube je neophodno staviti u transportni medijum i što pre, zajedno sa pacijentom uputiti stomatologu.

Vrsta medija u koji se pohranjuje zub i te kako utiče na dugoročnu prognozu replantiranog zuba. Idealni medij bi trebalo da očuva većinu funkcionalnih sposobnosti ćelija periodontalnog ligamenta [14].Zube ne bi trebalo sušiti, niti prenositi u suvom, što se događa prilikom umotavanja u maramice, gaze i slično. To dovodi do dehidratacije još uvek očuvanih ćelija na korenu, koje u suvom medijumu počinju izumirati. Postoje različiti mediji za čuvanje izbijenog zuba, kao što su široko dostupni (voda, pljuvačka, fiziološki rastvor, mleko...) i specijalizovani mediji. Voda može da štiti zub od dehidratacije, ali ako se koristi duže od 20 minuta dovodi do brzog propadanja ćelija periodontalnog ligamenta [16].

Pljuvačka je lako dostupan i povoljan medij za čuvanje ako se koristi kraće od sat vremena. Istraživanja su pokazala da je fiziološki rastvor kao sredina za čuvanje izbijenog zuba štetan za ćelije periodontalnog ligamenta ako se koristi duže od dva sata jer nema dovoljno esencijalnih hranjivih materija kao što su magnezijum, kalcijum i glukoza, koje su bitne za metaboličke potrebe periodoncijuma [17]. Savremena istraživanja navode mleko kao odličan medijum za čuvanje zuba i do šest sati jer nema bakterija, a ima pH i osmolalnost kompatibilne onima koji su kao ćelije periodontalnog ligamenta i ima hranljive materije kao što su aminokiseline, ugljeni hidrati i vitamini $[9,18$, 19]. Postoji više vrsta posebnih medijuma za prenos izbijenog zuba: Hankov izbalansirani rastvor soli (HBSS - Hank's Balanced Saline Solution), DentoSafe i ViaSpan medij za transplantaciju tkiva i organa $[3,19]$. Danas se smatra da je DentoSafe (Dentosafe GmbH, Iserlohn, Germany) najprikladniji medij za očuvanje i transport izbijenih zuba [16] te bi zbog toga DentoSafe bočice trebalo da budu dostupne na svim mestima rizičnim za nastanak dentalnih trauma, kao što su škole, vrtići, dečja igrališta i sportski tereni.

Pojedini autori ističu da je, u cilju prevencije nekroze pulpe avulziranog zuba, potrebno započeti korensko lečenje 7-10 dana od avulzije [14], što je u skladu sa našim postupkom. Svako dalje odlaganje povećava rizik od postreplantacione nekroze i gubitka zuba [16]. Komplikacije posle dentalne traume mogu se desiti u pulpi zuba, parodontalnom ligamentu i okolnim strukturama. Najčešće su nekroza pulpe [20] i resorpcija korena $[10,21]$. Našem pacijentu konstatovana je fistula iznad zuba 11 mesec dana i tri sedmice od povrede. Postojala je i perkutorna kao i palpatorna osetljivost pomenutog zuba. Pojedini autori ističu da je optimalna dužina nošenja imobilizacionog splinta za regeneraciju periodontalnog tkiva petnaest dana $[12,16]$. Naš pacijent je zbog veličine traumatskeog polja te zbog anodoncije zuba 22, kao i zbog palpatornog kliničkog nalaza, nosio splint 
duže od preporučenog vremena. U ovoj studiji pacijent je imao dva avulzirana zuba. Inače se obično dešava da je kod pacijenata traumatski ekstrahovan samo jedan zub [3].

Traume dentomaksilofacijalne regije imaju ozbiljne estetske, funkcionalne, psihološke i ekonomske posledice za pacijente i njihove roditelje $[16,22]$. Naš pacijent i njegovi roditelji nisu bili upoznati sa tim da je moguće da se zubi vrate u vilicu dok im stomatolog nije predložio takvu intervenciju. Inače, i druge studije rađene na tu temu pokazuju da je znanje roditelja o povredama zuba kao i mogućem lečenju neadekvatno [22,23]. Znanje o hitnom lečenju izbijenih zuba treba povećati pružanjem edukativnih i preventivnih informacija svima koji rade sa decom. Replantacija izbijenog zuba kod dece nije važna samo s funkcionalnog pogleda već ima veliki psihološki, emocionalni i socijalni značaj kako za dete tako i za roditelje. Rani gubitak zuba može da utiče negativno na psihosocijalni razvoj deteta. Zbog toga je važno edukovati sve osobe (roditelje, vaspitače, nastavno osoblje, sportske trenere) o prevenciji povreda, prvoj pomoći povređenih, mogućnosti replantacija avulziranih zuba kao i postupku i mogućem načinu transporta povređenih zuba. Medijumi za čuvanje izbijenog zuba trebalo bi da budu dostupni u svim vrtićima, školama i sportskim klubovima. U toku izvođenja sportskih aktivnosti, kako bi se sprečile ili ublažile povrede zuba, potrebno je da deca nose štitnike za zube. 